\title{
RISK FACTORS FOR SEVERE PNEUMONIA IN CHILDREN: A HOSPITAL BASED CASE - CONTROL STUDY
}

Dr. Ramesh. K, Varshitha Hemanth, Ashray. V, Safna. C. T, Anup. N.

1. Assistant Professor, Department of Community Medicine, Vijayanagara Institute of Medical Sciences, Bellary, Karnataka.

2. Junior Resident, Department of Community Medicine, Vijayanagara Institute of Medical Sciences, Bellary, Karnataka.

3. Junior Resident, Department of Community Medicine, Vijayanagara Institute of Medical Sciences, Bellary, Karnataka.

4. Junior Resident, Department of Community Medicine, Vijayanagara Institute of Medical Sciences, Bellary, Karnataka.

5. Junior Resident, Department of Community Medicine, Vijayanagara Institute of Medical Sciences, Bellary, Karnataka.

\section{CORRESPONDING AUTHOR}

Dr. Ramesh. K MBBS, MD, Assistant Professor,

Dept. of Community Medicine,

Vijayanagara Institute of Medical Sciences (VIMS),

Bellary -583104, Karnataka

E-mail: ramspsm@yahoo.co.in,

Ph: 00919481181291.

ABSTRACT: BACKGROUND: Pneumonia is the leading single cause of childhood mortality. The disease accounts for 19 per cent deaths in children less than 5 years. Pneumonia kills more children than any other illness, more than measles, malaria and AIDS combined. Globally 156 million new pneumonia cases are reported every year in the developing world. As many as 8.7 per cent of these cases are severe enough to be life-threatening and require hospitalization. In India, pneumonia is responsible for an estimated 410,000 deaths in children under five. Studies have shown that up to $19 \%$ of children hospitalized with pneumonia die in India. Most of the death occurs in severe pneumonia cases. Many studies have revealed the risk factors of pneumonia but very few studies have come out with risk factors of severe pneumonia and no study has been conducted in Karnataka to explore the risk factors of severe pneumonia. So we intended to do a study to find the risk factors of severe pneumonia. METHODOLOGY: This was a case-control study conducted between Jan 2010 to Sep 2010 in the Dept. of Pediatrics, Vijayanagara Institute of Medical Sciences, Bellary, Karnataka. . Cases were in-patients with severe pneumonia as ascertained by WHO criteria, while controls were out-patients with nonsevere acute respiratory infections. For each case we interviewed two controls. Totally 75 cases and 150 controls were included for the study. After obtaining consent from the parents, data was collected using a semi structured questionnaire and necessary anthropometric measurements were taken. Data was analyzed in SPSS 15.0 STATISTICAL ANALYSIS: proportion, Chi square test, odds ratio, logistic regression. RESULTS: The study subjects included 75 cases and 150 controls. The significant factors on univariate analysis were paternal and maternal education, joint type of family, delayed initiation of breast feeding, discontinuation of breastfeeding in young infants, PEM, low birth weight, previous history of ARI, immunocompromised state, similar cases in neighborhood, delivery by LSCS, birth order of 3or more, ANC visits less than 5, delayed initiation of treatment, increased distance of health care facility and use of solid fuel for cooking. Binary logistic regression revealed that PEM, previous history 
of ARI, delivery by LSCS and delayed initiation of treatment are strong associates of severe pneumonia. CONCLUSION: Many of the factors mentioned are amenable to corrective measures and may help in reducing the alarmingly high global burden of severe pneumonia.

KEYWORDS: Risk factor, Severe Pneumonia, case-control

INTRODUCTION: Pneumonia is the leading single cause of childhood mortality. The disease accounts for 19 per cent deaths in children less than 5 years. Pneumonia kills more children than any other illness, more than measles, malaria and AIDS combined. Globally 156 million new pneumonia cases are reported every year in the developing world. As many as 8.7 per cent of these cases are severe enough to be life-threatening and require hospitalization. India accounts for the maximum 43 million new cases followed by China ( 21 million cases) and Pakistan (10 million cases).(1)

In India, pneumonia is responsible for an estimated 410,000 deaths(1) in children under five. Studies have shown that up to $19 \%$ of children hospitalized with pneumonia die in India.

According to the 2008 estimates of WHO, pneumonia is the second leading cause of mortality in under-5 children (18\%) and the cause for highest mortality by a single specific disease among under-5 age group.(2)

As millions of children, specially the poor, remain at high risk of dying from pneumonia, it is a major factor causing delay in achieving the Millennium Development Goal of globally reducing childhood deaths by two-thirds by 2015.(1)

Childhood clinical pneumonia is caused by a combination of exposure to risk factors related to the host, the environment and infection. Possible risk factors(6) include malnutrition ,low birth weight, non-exclusive breastfeeding (during the first 4 months of life), immunization status, indoor air pollution(6)(7), overcrowding(10), concomitant diseases, mother's education and birth order etc. ${ }^{(6)}$

Many studies(4) (5)(9) have revealed the risk factors of pneumonia but very few studies have come out with risk factors of severe pneumonia and no study has been conducted in Karnataka to explore the risk factors of severe pneumonia. So we intended to do a study to find the risk factors of severe pneumonia.

Pneumonia constitutes about $17 \%$ of admissions to the Pediatric wards of Vijayanagara Institute Of Medical Sciences, Bellary, Karnataka, India. Keeping in view the burden of the disease, this study was conducted with the following objectives:

1) To study the risk factors of severe pneumonia among pediatric age group of 0-5 years

2) To study the difference in socio economic, nutrition, immunization, KAP factors among cases of pneumonia and severe pneumonia

METHODOLOGY;A case control study was conducted among children of the age group 0-5 yrs admitted to the Pediatric Dept. of Vijayanagara Institute Of Medical Sciences, Bellary, from January to September 2010.

Among the total 225 study subjects, cases comprised of in-patients with severe pneumonia as ascertained by WHO criteria, which were 75 in number; while controls were outpatients with non severe acute respiratory infections numbering to 150 .

Clinically pneumonia is classified as :(11)

I Very severe disease

Journal of Evolution of Medical and Dental Sciences/Volume1/ Issue4/October-2012 Page 358 
II Severe pneumonia

III Pneumonia (not severe)

IV No Pneumonia: cold or cough

The current WHO definition of very severe pneumonia is a clinical diagnosis based on the presence of cough or difficulty breathing plus at least one of the following: central cyanosis; inability to breast feed or drink, or vomiting everything; convulsions, lethargy or unconsciousness; or severe respiratory distress.

Severe respiratory distress is defined as the presence of head nodding in addition to other signs of respiratory distress such as chest indrawing and tachypnoea. This study intends to look at the risk factors for severe pneumonia.

Data was collected using a pre designed semi structured questionnaire which contained information regarding family \& socio economic conditions, birth \& immunization, nutritional aspects including breastfeeding details, past history, treatment details, KAP and health seeking behaviour.

Age of the child was recorded in completed months. Family type was classified as Nuclear /Joint / Three generation family. The family size and number of members with history of ARI (Acute respiratory infection) in the past one month were recorded.

Education of mother and father was graded according to the following scale:

1) Illiterate

2) Primary schooling

3) Secondary schooling

4) Higher secondary schooling

5) Pre - University.

6) Degree and higher.

The occupation of the mother and father was graded as follows:

1) Unemployed.

2) Unskilled.

3) Semiskilled.

4) Skilled.

5) Professional.

6) Business and others.

The Monthly Family income was recorded.

History of immunization was elicited from parents and verified by checking the written document wherever available. A child was assessed to be completely immunized if he/she had received all vaccinations due for his age according to national immunization schedule. The child was also categorized as being immunocompromised if he had/has HIV/HBV/Measles.

Birth history included birth order (6), antenatal history, perinatal history and postnatal history. Details about the mother during the antenatal check up, tetanus immunization and iron \& folic acid supplementation were also collected.

History of breastfeeding and the age of introduction of supplementary feeding was elicited. Caloric intake of the child was calculated by recording the food items given to the child regularly prior to the current illness by $24 \mathrm{hr}$ recall method.

Journal of Evolution of Medical and Dental Sciences/Volume1/ Issue4/October-2012 Page 359 
The Indian Association Of Pediatrics classification was used for assessing the grade of malnourishment among the study subjects. BMI was also calculated.

Details of the illness including duration of illness, time of initiation of initial treatment and referral from other places were recorded. History of previous similar attacks,T.B contact, history of measles and similar complaints in the neighbourhood, school or family was elicited.

Housing conditions included type of house, locality (rural/urban \& slum/non slum), ventilation, water supply, waste disposal and overcrowding.

Overcrowding was determined by calculating number of family members per room (3). A child who was not found to be in the following norm was labeled as staying in overcrowded house.

1 Room 2 persons

2 Rooms 3 persons

3 Rooms 5 persons

4 Rooms 7 persons

5 or more rooms 10 persons (additional 2 for each further room).

Usage of solid fuel for cooking(7),(8) was also recorded.

Knowledge , Attitude and Practices of the parents comprising mode of transmission, belief of disease being curable or not, use of handkerchief while sneezing/coughing, sanitary disposal of sputum, isolation of the patient after onset of symptoms (P) and hygiene of the child .

Health seeking behavior such as approaching the nearest health facility at the time of illness was included.

RESULTS: Table.no1 shows the age sex wise distribution of study subjects which includes both cases and controls. $61.3 \%$ is contributed by males and the remaining $38.7 \%$ by females. 107 subjects belonged to the age group of 2 months- 12 months. $62.6 \%$ males were from the 2 mo$12 \mathrm{mo}$ age group and among female subjects; majority (ie $41.1 \%$ ) belonged to the age group of $12 \mathrm{mo}$ to 5 years.

Table 1- Age sex wise distribution of study subjects

\begin{tabular}{|l|l|l|l|}
\hline \multicolumn{1}{|c|}{ Age group } & \multicolumn{1}{|c|}{ Male } & \multicolumn{1}{c|}{ Female } & \multicolumn{1}{c|}{ Total } \\
\hline$<2$ months & $18(64.3 \%)$ & $10(35.7 \%)$ & $28(100 \%)$ \\
\hline 2 months -12 months & $67(62.6 \%)$ & $40(37.4 \%)$ & $107(100 \%)$ \\
\hline$>12$ months -5 years & $53(58.9 \%)$ & $37(41.1 \%)$ & $90(100 \%)$ \\
\hline Total & $138(61.3 \%)$ & $87(38.7 \%)$ & $225(100 \%)$ \\
\hline
\end{tabular}

Table 2 shows the Socio-demographic factors considered to study the risk associated with severe pneumonia.

In the study, majority $(46.8 \%)$ of the children suffering from severe pneumonia were aged between $12 \mathrm{mo}$ and $5 \mathrm{yrs}$. Though majority of the cases were males(62.6\%), it was not found 
to be significant $(\mathrm{p}=0.88)$.The joint family type was found to be significantly associated with severe pneumonia $(68 \%)(\mathrm{p}=0.02)$.

The paternal $(70.6 \%)(\mathrm{p}=0.01)$ and maternal education $(81.3 \%)(\mathrm{p}=0.01)$ only upto the primary level was positively associated with incidence of severe pneumonia. Significantly more fathers were found to be either unemployed or unskilled in the severe pneumonia group (84\%) $(\mathrm{p}=0.04)$, however maternal occupation did not show significant risk associated with severe pneumonia $(\mathrm{p}=0.29)$.

Table 2: Socio-demographic factors

\begin{tabular}{|c|c|c|c|c|}
\hline Variables & $\begin{array}{l}\text { Cases } \\
(\mathrm{N}=75)\end{array}$ & $\begin{array}{l}\text { Controls } \\
(\mathrm{N}=150)\end{array}$ & $\begin{array}{ll}\text { Odds } & \text { ratio } \\
(95 \mathrm{CI} \%) & \end{array}$ & $P$ value \\
\hline $\begin{array}{l}\text { Age } \\
<2 \text { months } \\
2-12 \text { months } \\
>12 \text { months }-5 \text { yrs }\end{array}$ & $\begin{array}{l}08(10.6 \%) \\
32(42.6 \%) \\
35(46.8 \%)\end{array}$ & $\begin{array}{l}20(13.3 \%) \\
75(50.0 \%) \\
55(36.7 \%)\end{array}$ & ------ & 0.35 \\
\hline $\begin{array}{l}\text { Sex } \\
\text { Male } \\
\text { Female }\end{array}$ & $\begin{array}{l}47(62.6 \%) \\
28(37.4 \%)\end{array}$ & $\begin{array}{l}91(60.6 \%) \\
59(39.4 \%)\end{array}$ & $\begin{array}{l}1.08 \\
(0.61-1.92)\end{array}$ & 0.88 \\
\hline $\begin{array}{l}\text { Family type } \\
\text { Joint family } \\
\text { Nuclear family }\end{array}$ & $\begin{array}{l}51(68.0 \%) \\
24(32.0 \%)\end{array}$ & $\begin{array}{l}79(52.6 \%) \\
71(47.4 \%)\end{array}$ & $\begin{array}{l}1.91 \\
(1.03-3.56)\end{array}$ & 0.02 \\
\hline $\begin{array}{l}\text { Family size } \\
>5 \text { members } \\
<5 \text { members }\end{array}$ & $\begin{array}{l}56(74.6 \%) \\
19(25.4 \%)\end{array}$ & $\begin{array}{l}97(64.6 \%) \\
53(35.4 \%)\end{array}$ & $\begin{array}{l}1.61 \\
(0.83-3.14)\end{array}$ & 0.12 \\
\hline $\begin{array}{l}\text { Paternal education } \\
<\text { Primary } \\
>\text { Primary }\end{array}$ & $\begin{array}{l}53(70.6 \%) \\
22(29.4 \%)\end{array}$ & $\begin{array}{l}87(58.0 \%) \\
63(42.0 \%)\end{array}$ & $\begin{array}{l}2.13 \\
(1.11-4.13)\end{array}$ & 0.01 \\
\hline $\begin{array}{l}\text { Maternal education } \\
<\text { Primary }\end{array}$ & $61(81.3 \%)$ & 99 (66.0\%) & 2.24 & 0.01 \\
\hline
\end{tabular}




\begin{tabular}{|l|l|l|l|l|}
\hline$>$ Primary & $14(18.7 \%)$ & $51(34.0 \%)$ & $(1.10-4.65)$ & \\
\hline Paternal occupation & & $108(72.0 \%)$ & 2.04 & 0.04 \\
Unemployed/unskilled & $63(84.0 \%)$ & $42(28.0 \%)$ & $(0.95-4.44)$ & \\
Semi/skilled & $12(16.0 \%)$ & $131(87.3 \%)$ & 1.67 & 0.29 \\
\hline Maternal occupation & $69(92.0 \%)$ & $19(12.7 \%)$ & $(0.59-4.92)$ & \\
Unemployed/unskilled & $06(08.0 \%)$ & & & \\
\hline
\end{tabular}

Table 3 shows the variables studied for housing conditions. Amongst the 6 housing conditions variables, kuchcha type of housing $(73.3 \%) \quad(\mathrm{p}=0.00)$, residence in slum area $(46.6 \%)(\mathrm{p}=0.03)$,inadequateventilation $(76 \%)(\mathrm{p}=0.04)$,overcrowding $(81.3 \%)(\mathrm{p}=0.00)$ and use of solid cooking fuel $(85.3 \%)(\mathrm{p}=0.00)$ were found to be significant risk factors for severe pneumonia.

Table 3: Housing conditions

\begin{tabular}{|l|l|l|l|l|}
\hline Variables & Cases & Controls & Odds ratio & P value \\
Kuching type & $(\mathrm{N}=75)$ & $(95 \mathrm{Cl} \%)$ & \\
Pucca & $55(73.3 \%)$ & $70(46.6 \%)$ & 3.14 & 0.00 \\
\hline Locality & $20(26.7 \%)$ & $80(53.4 \%)$ & $(1.65-6.02)$ & \\
Rural & $48(64.0 \%)$ & $110(73.3 \%)$ & 0.65 & 0.14 \\
Urban & $27(36.0 \%)$ & $40(26.7 \%)$ & $(0.34-1.22)$ & \\
\hline Area & $35(46.6 \%)$ & $49(32.6 \%)$ & 1.80 & 0.03 \\
Slum & $40(53.4 \%)$ & $101(67.4 \%)$ & $(0.98-3.31)$ & \\
\hline Non slum & $57(76.0 \%)$ & $94(62.6 \%)$ & 1.89 & \\
\hline Ventilation & & & & \\
\hline
\end{tabular}




\begin{tabular}{|c|c|c|c|c|}
\hline Adequate & $18(24.0 \%)$ & $56(27.4 \%)$ & $(0.97-3.70)$ & \\
\hline \multicolumn{5}{|c|}{ Overcrowding } \\
\hline Present & 61 (81.3\%) & $92(61.3 \%)$ & 2.75 & 0.00 \\
\hline Absent & 14 (18.7\%) & $58(38.7 \%)$ & $(1.35-5.67)$ & \\
\hline \multicolumn{5}{|c|}{ Cooking fuel } \\
\hline Solid fuel & 64 (85.3\%) & 86 (57.3\%) & 4.33 & 0.00 \\
\hline Others & 11 (14.7\%) & 64 (42.7\%) & $(2.02-9.48)$ & \\
\hline
\end{tabular}

Table 4 includes the pregnancy and birth related factors among which less than 3 ante natal check up visits $(68 \%)(p=0.00)$, Ceasarean section mode of delivery $(74.6 \%)(p=0.00)$, low birth weight $(84 \%)(p=0.01)$ and delayed initiation of breast feeding were of significance in children suffering with severe pneumonia.

However, the place of delivery, birth order and exclusive breast feeding were found to have no implications on occurrence of severe pneumonia.

\section{Table 4: Pregnancy and birth related factors}

\begin{tabular}{|c|c|c|c|c|}
\hline Variables & $\begin{array}{l}\text { Cases } \\
(\mathrm{N}=75)\end{array}$ & $\begin{array}{l}\text { Controls } \\
(\mathrm{N}=150)\end{array}$ & Odds ratio $(95 \mathrm{Cl} \%)$ & $P$ value \\
\hline $\begin{array}{l}\text { ANC reg } \\
\text { Yes } \\
\text { No }\end{array}$ & $\begin{array}{l}47(62.6 \%) \\
28(37.4 \%)\end{array}$ & $\begin{array}{l}91(60.6 \%) \\
59(39.4 \%)\end{array}$ & $\begin{array}{l}1.15 \\
(0.27-4.57)\end{array}$ & 1.00 \\
\hline $\begin{array}{l}\text { ANC visits } \\
<3 \text { visits } \\
>3 \text { visits }\end{array}$ & $\begin{array}{l}51(68.0 \%) \\
24(32.0 \%)\end{array}$ & $\begin{array}{l}79(52.6 \%) \\
71(47.4 \%)\end{array}$ & $\begin{array}{l}2.39 \\
(1.30-4.41)\end{array}$ & 0.00 \\
\hline $\begin{array}{l}\text { Mode of } \\
\text { delivery } \\
\text { LSCS } \\
\text { NVD }\end{array}$ & $\begin{array}{l}56(74.6 \%) \\
19(25.4 \%)\end{array}$ & $\begin{array}{l}97(64.6 \%) \\
53(35.4 \%)\end{array}$ & $\begin{array}{l}2.64 \\
(1.43-4.90)\end{array}$ & 0.00 \\
\hline Place of & & & & \\
\hline
\end{tabular}

Journal of Evolution of Medical and Dental Sciences/Volume1/ Issue4/October-2012 Page 363 
ORIGINAL ARTICLE

\begin{tabular}{|c|c|c|c|c|}
\hline $\begin{array}{l}\text { delivery } \\
\text { Home } \\
\text { Institution }\end{array}$ & $\begin{array}{l}53(70.6 \%) \\
22(29.4 \%)\end{array}$ & $\begin{array}{l}87(58.0 \%) \\
63(42.0 \%)\end{array}$ & $\begin{array}{l}1.34 \\
(0.70-2.57)\end{array}$ & 0.34 \\
\hline $\begin{array}{l}\text { Birth order } \\
</=2 \\
>2\end{array}$ & $\begin{array}{l}61(81.3 \%) \\
14(18.7 \%)\end{array}$ & $\begin{array}{l}99(66.0 \%) \\
51(34.0 \%)\end{array}$ & $\begin{array}{l}0.85 \\
(0.46-1.55)\end{array}$ & 0.56 \\
\hline $\begin{array}{l}\text { Birth weight } \\
<2500 \text { gms } \\
>2500 \text { gms }\end{array}$ & $\begin{array}{l}63(84.0 \%) \\
12(16.0 \%)\end{array}$ & $\begin{array}{l}108(72.0 \%) \\
42(28.0 \%)\end{array}$ & $\begin{array}{l}2.11 \\
(1.14-3.90)\end{array}$ & 0.01 \\
\hline $\begin{array}{l}\text { Initiation of } \\
\mathrm{BF} \\
<4 \mathrm{hrs} \\
>4 \mathrm{hrs}\end{array}$ & $\begin{array}{l}69(92.0 \%) \\
06(08.0 \%)\end{array}$ & $\begin{array}{l}131(87.3 \%) \\
19(12.7 \%)\end{array}$ & $\begin{array}{l}2.40 \\
(1.05-4.24)\end{array}$ & 0.02 \\
\hline $\begin{array}{l}\text { Exclusive BF } \\
\text { Present } \\
\text { Absent }\end{array}$ & $\begin{array}{l}71(94.6 \% \\
04(5.4 \%)\end{array}$ & $\begin{array}{l}129(86.0 \%) \\
11(14.0 \%)\end{array}$ & $\begin{array}{l}1.14 \\
(0.53-2.43)\end{array}$ & 0.72 \\
\hline
\end{tabular}

\section{The illness related factors are shown in Table 5.}

Presence of PEM (Protein energy Malnutrition) $(61.3 \%)(\mathrm{p}=0.00)$, history of previous attacks $(78.6 \%)(p=0.00)$, initiation of treatment after first 24 hours of illness $(65.3 \%)(p=0.00)$, healthcare accessibility ( health care facility farther than $2 \mathrm{~km})(62.6 \%)(\mathrm{p}=0.00)$ were found to be significantly associated with severe pneumonia.

According to our study, immunization, history of ARI in family and history of measles were not found to be significant risk factors among children with severe pneumonia in comparison to children suffering from pneumonia. 
Table 5: Illness related factor

\begin{tabular}{|c|c|c|c|c|}
\hline Variables & $\begin{array}{l}\text { Cases } \\
(\mathrm{N}=75)\end{array}$ & $\begin{array}{l}\text { Controls } \\
(\mathrm{N}=150)\end{array}$ & $\begin{array}{l}\text { Odds ratio } \\
(95 \mathrm{Cl} \%)\end{array}$ & $P$ value \\
\hline Immunization & & & & \\
\hline $\begin{array}{l}\text { Full } \\
\text { No/partial }\end{array}$ & $\begin{array}{l}74(98.6 \%) \\
01(1.4 \%)\end{array}$ & $\begin{array}{l}147(98.0 \%) \\
03(2.0 \%)\end{array}$ & $\begin{array}{l}1.51 \\
(0.14-8.17)\end{array}$ & 1.00 \\
\hline PEM & & & & \\
\hline $\begin{array}{l}\text { Present } \\
\text { Absent }\end{array}$ & $\begin{array}{l}46(61.3 \%) \\
29(38.7 \%)\end{array}$ & $\begin{array}{l}51(34.0 \%) \\
99(66.0 \%)\end{array}$ & $\begin{array}{l}3.08 \\
(1.67-5.70)\end{array}$ & 0.00 \\
\hline H/o ARI in fam & & & & \\
\hline $\begin{array}{l}\text { Yes } \\
\text { No }\end{array}$ & $\begin{array}{l}21(28.0 \%) \\
54(72.0 \%)\end{array}$ & $\begin{array}{l}32(21.3 \%) \\
118(78.7 \%)\end{array}$ & $\begin{array}{l}1.43 \\
(0.72-2.84)\end{array}$ & 0.26 \\
\hline H/o measles & & & & \\
\hline $\begin{array}{l}\text { Yes } \\
\text { No }\end{array}$ & $\begin{array}{l}02(2.6 \%) \\
73(97.4 \%)\end{array}$ & $\begin{array}{l}01(0.6 \%) \\
149(99.4 \%)\end{array}$ & $\begin{array}{l}4.09 \\
(0.28-115.6)\end{array}$ & 0.25 \\
\hline H/o previous & & & & \\
\hline $\begin{array}{l}\text { Yes } \\
\text { No }\end{array}$ & $\begin{array}{l}59(78.6 \%) \\
16(21.4 \%)\end{array}$ & $\begin{array}{l}73(48.6 \%) \\
77(51.4 \%)\end{array}$ & $\begin{array}{l}3.89 \\
(1.97-7.76)\end{array}$ & 0.00 \\
\hline Initiation of $\mathrm{R}$ & & & & \\
\hline $\begin{array}{l}>24 \mathrm{hrs} \\
<24 \mathrm{hrs}\end{array}$ & $\begin{array}{l}49(65.3 \%) \\
26(34.7 \%)\end{array}$ & $\begin{array}{l}69(46.0 \%) \\
81(54.0 \%)\end{array}$ & $\begin{array}{l}2.21 \\
(1.20-4.09)\end{array}$ & 0.00 \\
\hline $\begin{array}{l}\text { Place of initial } \\
\text { Private } \\
\text { Government }\end{array}$ & $\begin{array}{l}35(46.6 \%) \\
40(53.4 \%)\end{array}$ & $\begin{array}{l}37(24.6 \%) \\
113(75.4 \%)\end{array}$ & $\begin{array}{l}2.67 \\
(1.43-5.01)\end{array}$ & 0.00 \\
\hline
\end{tabular}




\begin{tabular}{|l|l|l|l|l|}
\hline Healthcareaccessibility & & & \\
Within 2 kms & $47(62.6 \%)$ & $59(39.3 \%)$ & 2.59 & 0.00 \\
\hline
\end{tabular}

On multivariate analysis by binary logistic regression, presence of PEM, previous history of ARI, mode of delivery by ceasarian section, delayed initiation of treatment and failure to initiate breast feeding within 4 hours of birth were found to be strong associates of severe pneumonia.

Table 6: Binary logistic regression

\begin{tabular}{|l|l|l|}
\hline Variables & Adjusted odds ratio & P value \\
\hline PEM & $4.01(2.34-6.89)$ & 0.00 \\
\hline Previous history of ARI & $2.92(1.96-8.13)$ & 0.00 \\
\hline Delivery by LSCS & $2.86(1.34-7.11)$ & 0.00 \\
\hline Delayed initiation of treatment & $2.01(1.88-6.98)$ & 0.00 \\
\hline Failure to initiate breast & $1.67(1.18-8.56)$ & 0.00 \\
feeding within 4 hours & & \\
\hline
\end{tabular}

DISCUSSION: Socio-demographic factors: In socio-demographic factors variables like joint family, paternal and maternal education upto or less than primary and paternal occupation unemployed / unskilled were found to be statistically significant. Family plays an important role both in health and disease- in the prevention and treatment of individual illness, in the care of children and in the stabilization of the personality of both adults and children.

In our study, severe pneumonia was more common among children living in joint type of family, it may be due to the more family members and overcrowding which makes joint family a playground for communicable diseases. These diseases are known to spread rapidly in families because of the common environment which the family members share.

Income, education and occupation are the major components of most measures of social class and are generally positively correlated with health status. Diseases of respiratory system, eyes and skin, diarrhea have a higher incidence in lower classes which can be ascribed to the poor state of physical environment in which they live. Individuals in the lower social classes have been found to make less use of hospital facilities, consult the doctor less often and are less 
likely to be aware and utilize preventive health services such as prenatal and postnatal care, general check ups and immunization services.

Housing conditions: In housing conditions, the association of kuchcha/ semi pucca type of housing, slum area, presence of overcrowding, inadequate ventilation and use of solid cooking fuel were found to be statistically associated with severe pneumonia.

Housing is a part of the total environment of man and being a part of it is to some extent responsible for the state of man's health and well being. A strong relationship is established between poor housing and respiratory infections. High morbidity and mortality rates are observed where housing conditions are sub- standard

In kuchcha/ semi pucca houses the walls and floors are permeable to water, remains damp, mud floors tend to break up and the cracks and crevices results in harbourage of dusts and insects, inadequate ventilation and these factors contribute to the ill health of its inmates.

In our study it has been found out that children living in kuccha/ semi pucca houses are three times more susceptible to develop severe pneumonia.

Ventilation controls indoor humidity and airborne contaminants, both of which either contribute to or act as health hazards. Inadequate ventilation can increase indoor pollutant levels by not bringing in enough outdoor air to dilute emissions from indoor sources and by not carrying indoor air pollutants out of home.

Use of biomass fuels (wood, crop residues, animal dung) coal and other media( kerosene) are predominant contributors to indoor air pollution. More than three- quarters of all Indian households are dependent on such fuels. These are burnt in simple stoves with incomplete combustion generating a lot of toxic products that adversely affect specific and non specific local defenses of the respiratory tract. The risk is highest for mothers and children due to longer stay indoors and close proximity during cooking(7). This study shows that children living in houses where solid cooking fuel is used, have 4.33 times the risk of developing severe pneumonia when compared to children from homes where other fuels are used. Studies conducted elsewhere have also concluded that indoor air pollution is a major contributory factor in the development of respiratory tract infection (5)(7).

Slums are breeding grounds for social problems and many communicable diseases especially respiratory diseases. They exhibit high rates of disease due to unsanitary conditions, malnutrition and lack of basic health services.

Overcrowding is a health problem in human dwellings. It promotes the spread of respiratory infections among other communicable diseases. There are higher chances of spread of respiratory disease by droplet transmission which is one of the major modes of transmission especially in pneumonia. A few previous studies also have similar findings (4) (5) (9).

The variable of locality (rural/urban) was found to be statistically insignificant in our study, it may be due to the almost equal distribution of study subjects in rural and urban areas and may be also due to the small sample size.

Pregnancy and birth related factors: In our study ANC visits less than three, delivery by caesarian section, birth weight less than $2500 \mathrm{gm}$, failure to initiate breast feeding within $4 \mathrm{hrs}$ were found to be statistically significant. These variables carry about 2 times risk of developing severe pneumonia.

Birth weight of an infant is the single most important determinant of its chance of survival, healthy growth and development. Most of the low birth weight infants become victims of PEM and infections. Low birth weight also reflects inadequate nutrition and ill health of the 
mother. There is a strong and significant positive correlation between maternal nutritional status and the duration of pregnancy and birth weight.

Antenatal checkup aims at achieving, at the end of pregnancy a healthy mother and a healthy baby. In our study ANC less than 3 has emerged as one of the factors for development of severe pneumonia. This may be due inadequate nutrition and ill health of the mother and failure to identify the high risk cases. Improper ANC can increase the likelihood of delivery by caesarian section which may be either elective or emergency.

The earlier studies have not taken into consideration factors related to ante natal care and mode of delivery. In our study ANC registration, place of delivery, birth order less than 3, exclusive breast feed were found to be statistically insignificant. This may be due to the smaller study group wherein, most of the study subjects belonged to rural areas and that most of the deliveries, even though conducted at home, were under the supervision of trained dais.

Illness related factors: In our study, presence of PEM, history of previous attacks of ARI, initiation of treatment after more than 24 hours of onset of symptoms and health care accessibility (distance from home more than $2 \mathrm{Km}$ ) have been found to be statistically significant.

Health care accessibility can affect the outcome of the disease. The disease progresses faster in young children owing to their immature immune system. In our study children residing at places where health care accessibility is more than $2 \mathrm{Km}$ and with initial treatment after more than 24 hours, are found to suffer more from severe pneumonia. In a study conducted earlier, delayed reporting to health care facility did not emerge as a risk factor (9).

As per treatment guidelines, children with severe disease require immediate admission and treatment to decrease morbidity and mortality.

In our study, immunization, history of ARI in the family and history of measles were found to statistically insignificant. This may be attributable due to the following: Inadequate awareness among parents about immunization schedule, symptoms of ARI and measles. Also, in our study we have made a comparison between children suffering from pneumonia and those from severe pneumonia whereas in other studies, comparison has been made with healthy children ${ }^{(5)}$ or no comparison has been made ${ }^{(9)}$.

Multivariate analysis revealed PEM to be a major risk factor in causing severe pneumonia in our study. In the previous studies too, it has been found to be a significant risk factor ${ }^{(5)(4) . ~ P E M ~ i s ~ w e l l ~ k n o w n ~ t o ~ c a u s e ~ d e c r e a s e d ~ i m m u n i t y ~ a m o n g ~ c h i l d r e n ~ a n d ~ h e n c e ~ d i r e c t l y ~}$ predisposes a child to be more susceptible for severe pneumonia.

Our study reveals that children with previous history of ARI had 2.92 times more risk of developing severe pneumonia against pneumonia. The previous studies also have similar findings. This may be attributable to the damage to the respiratory epithelium / parenchyma by previous ARI causing increased susceptibility to respiratory infections.

Delivery of children by Caesarian section had 2.86 times more risk of developing severe pneumonia when compared to children born by normal vaginal delivery. Studies conducted earlier ${ }^{(5)(4)}$ have not focused on this aspect as being a risk factor for pneumonia. However, in this study, analysis revealed that birth by caesarian section is a significant risk factor for severe pneumonia.

This may be attributed to delayed onset of breast feeding (more than $4 \mathrm{hrs}$ after birth) in children born by caesarian section and increased use of respiratory resuscitation measures causing a higher risk for respiratory infections in children.

Journal of Evolution of Medical and Dental Sciences/Volume1/ Issue4/October-2012 Page 368 
Infrequent and improper antenatal checkups can also contribute to increase in births by emergency caesarian section which is known to increase maternal and child morbidity. Delayed initiation of treatment ( $>24 \mathrm{hrs}$ after the onset of symptoms first appeared) had a strong association with occurrence of severe pneumonia in our study.

Earlier studies have analyzed that patients required change of antibiotics $48 \mathrm{hrs}$ after admission (9).

This highlights the importance of early initiation of treatment, the failure of which causes increased severity of symptoms and hence occurrence of severe pneumonia.

Previous studies conducted to reveal the risk factors of pneumonia have found that, lack of breast feeding(9) , discontinuation of breastfeeding(4), no breastfeeding or breastfeeding less than 4 months ${ }^{(5)}$ were significant risk factors for causing pneumonia .

In this study we have found the presence of delayed initiation of breastfeeding (by more than 4 hrs after birth) to be a significant factor in causing severe pneumonia among children. This can be attributed to the fact that babies breastfed for the $1^{\text {st }}$ time after more than $4 \mathrm{hrs}$ after birth were less likely to be colostrum fed than their counterparts being fed for the first time within $4 \mathrm{hrs}$ after birth. Babies with delayed initiation of breast feeding were more likely to be given pre lacteal feeds like honey, water, jaggery, castor oil etc. Colostrum is known to have higher content of maternal antibodies and vitamins $\mathrm{A}, \mathrm{E}$ and hence provides better immunity in children decreasing the risk of developing severe pneumonia.

CONCLUSION: In our study, PEM, previous history of ARI, delivery by LSCS , delayed initiation of treatment and failure to initiate breast feeding within four hours of delivery are significantly associated with severe pneumonia and hence these factors can be considered for screening severe pneumonia among children

\section{REFERENCES:}

1. WHO Article - World Pneumonia day 2009.

2. WHO Statistics on under 5 mortality 2008.

3. Park K. Environment and health In: Textbook of Preventive and Social Medicine. 20th edn. Ed. Park K, Jabalpur, Banarasidas Bhanot Publishers, 2009; pp 658.

4. Shah N, Ramankutty V, Premila PG, Sathy N (1994) Risk factors for severe pneumonia in children in south Kerala: a hospital-based case-control study. Journal of Tropical Pediatrics, 40:201-206.

5. S.Broor , R.M. Pandey, M.Ghosh, R.S.Maitreyi, Rakesh Lodha, Tanu Singhal \& S.K. Kabra Risk Factors for Severe Acute Lower Respiratory Tract infection in under five children , Indian Pediatrics 2001; 38: 1361-1369.

6. Murali Narayanan , AG Falade - Clinical Risk Factors for Death in Children with Pneumonia ; www.ichrc.org ,First published online: 13th October 2006.

7. Kirk R Smith, Jonathan M Samet, Isabelle Romieu, Nigel Bruce - Indoor air pollution in developing countries and acute lower respiratory infections in children; Thorax 2000;55:518-532.

8. Louis Niessen, Anne ten Hove, Henk Hilderink, Martin Weber, Kim Mulholland \& Majid Ezzati - Comparative impact assessment of child pneumonia interventions , Bulletin of the World Health Organization 2009;87:472-480. doi: 10.2471/BLT.08.050872.

Journal of Evolution of Medical and Dental Sciences/Volume1/ Issue4/October-2012 Page 369 
9. Karalanglin Tiewsoh, Rakesh Lodha, Ravindra M Pandey, Shobha Broor, M Kalaivani, Sushil K Kabra: Factors determining the outcome of children hospitalized with severe pneumonia: BMC Pediatrics 2009, 9:15doi:10.1186/1471-2431-9-15

10. Maria Regina Alves Cardoso,Simon Nicholas Cousens,Luiz Fernando de Góes Siqueira, Fátima Maria Alves ,LuizAntônio V D'Angelo : Crowding: risk factor or protective factor for lower respiratory disease in young children?: BMC Public Health 2004, 4:19doi:10.1186/1471-2458-4-19

11. Park K. Epidemiology of communicable diseases, Acute respiratory diseases In: Textbook of Preventive and Social Medicine. 20th edn. Ed. Park K, Jabalpur, Banarasidas Bhanot Publishers, 2009; pp 154. 